\title{
Generalized Molluscum contagiosum in an HIV infected patient
}

\author{
Ovidiu Roşca ${ }^{1 *}$, Andreea Ardeleanu², Caius Solovan ${ }^{3}$ \\ From The 7th Romanian National HIV/AIDS Congress and The 2nd Central European HIV Forum \\ Sibiu, Romania. 29-31 May 2014
}

Molluscum contagiosum is a benign contagious disease caused by a poxvirus. In an immunocompetent host molluscum contagiosum is most frequently a self-limiting benign viral disease of the skin and rarely of the mucous membranes. Atypical forms of molluscum contagiosum may be challenging to diagnose and are found in immunocompromised patients where they indicate severe impairment of cellular immunity. We report the case of a 45-years old patient admitted in our department in January 2014, for skin-colored and violaceus, painless papules and nodules on the arms, forearms, chest, face, inguinal and genital regions; the lesions appeared about 6 months ago, on the upper limbs and progressively extended. The patient was diagnosed with HIV infection in 2011, but did not follow antiretroviral therapy and never submitted to control until January 2014. In January 2014: CD4: 40 cells/ $\mu \mathrm{L}$, viral load: 112,617 copies/mL. He received antiviral therapy with acyclovir topical local therapy and antiretroviral treatment and evolution was favorable.

\begin{abstract}
Authors' details
${ }^{1}$ Department of Infectious Diseases I, Dr. Victor Babeș University of Medicine and Pharmacy, Timişoara, Romania. ${ }^{2}$ Department of Infectious Diseases I, Dr. Victor Babeş Clinical Hospital of Infectious Diseases and Pneumology,

Timişoara, Romania. ${ }^{3}$ Department of Dermatology, Dr. Victor Babeş University of Medicine and Pharmacy, Timişoara, Romania.
\end{abstract}

Published: 29 May 2014

'Department of Infectious Diseases I, Dr. Victor Babeş University of Medicine and Pharmacy, Timişoara, Romania

Full list of author information is available at the end of the article

Submit your next manuscript to BioMed Central and take full advantage of:

- Convenient online submission

- Thorough peer review

- No space constraints or color figure charges

- Immediate publication on acceptance

- Inclusion in PubMed, CAS, Scopus and Google Scholar

- Research which is freely available for redistribution
() Biomed Central

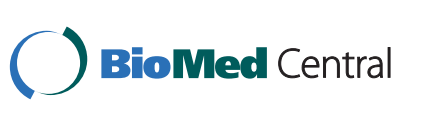

